\title{
Gestational Diabetes in a High-Risk Population: Perinatal Outcomes with Impaired Fasting Plasma Glucose
}

\author{
Tarik Y. Yamani Zamzami, MD, CABOG \\ Department of Obstetrics and Gynecology, Faculty of Medicine \\ King Abdulaziz University, Jeddah, Saudi Arabia \\ tarikyamani@hotmail.com
}

\begin{abstract}
The aim of the study was to compare the perinatal outcomes of gestational diabetic patients with normal fasting plasma glucose level $<5.3 \mathrm{mmol} / \mathrm{L}$, versus impaired fasting plasma glucose level $\geq 5.3$ $\mathrm{mmol} / \mathrm{L}$ on $100 \mathrm{~g}$ oral glucose tolerance results. All gestational diabetic patients enrolled in the study were diagnosed by standard $100 \mathrm{~g}$ oral glucose blood samples. Based on oral glucose tolerance results, patients were divided into two groups according to the fasting plasma glucose; Group 1 normal fasting plasma glucose $<5.3 \mathrm{mmol} / \mathrm{L}$, and Group 2 impaired fasting plasma glucose $\geq 5.3 \mathrm{mmol} / \mathrm{L}$. During the study period, a total of 292 patients were identified as having gestational diabetes mellitus. One hundred eighty-two (62.3\%) were with normal fasting plasma glucose $<5.3 \mathrm{mmol} / \mathrm{L}$ and $110(37.7 \%)$ patients had impaired fasting plasma glucose $\geq 5.3 \mathrm{mmol} / \mathrm{L}$. The percentage of total and primary cesarean delivery and the arithmetic means \pm SD of all fasting and postprandial plasma glucose measurements were significantly lower in-Group 1 compared with Group 2 patients. Patients with impaired fasting plasma glucose needed more insulin therapy and were associated with a higher rate of cesarean delivery compared to patients with normal fasting plasma glucose who may need ordinary follow-up rather than frequent surveillance.
\end{abstract}

Keywords: Fasting plasma glucose, Macrosomia, Cesarean delivery, and Gestational diabetes mellitus.

Correspondence \& reprint request to: $\quad$ Dr. Tarik Y. Yamani Zamzami

P.O. Box 80215, Jeddah 21589, Saudi Arabia

Accepted for publication: 17 December 2007. Received: 13 November 2007. 


\section{Introduction}

Perinatal mortality among the infants of mothers with gestational diabetes mellitus has been reduced to the rate that is not totally different than that of the general non-diabetic population ${ }^{[1-3]}$. Improved perinatal care has prevented such increase in perinatal mortality. On the other hand, maternal and perinatal morbidity continue to be high. Uncontrolled hyperglycemia of the gestational diabetes mellitus (GDM) is associated with increased macrosomia and operative delivery ${ }^{[4]}$. In addition, longterm studies have shown that patients with GDM have an increased risk of developing non-insulin-dependent diabetes mellitus ${ }^{[5]}$. The GDM diagnosis encompasses a heterogeneous spectrum of glucose intolerance. There is insufficient data on impaired fasting glucose (IFG) and impaired glucose tolerance (IGT), and in most studies, IFG was included under IGT. Therefore this study was undertaken to determine the perinatal outcomes of gestational diabetic patients with normal fasting plasma glucose level $<5.3 \mathrm{mmol} / \mathrm{L}$ vs. impaired fasting plasma glucose $\geq 5.3$ $\mathrm{mmol} / \mathrm{L}$ using $100 \mathrm{~g}$ oral glucose tolerance (OGTT).

\section{Material and Methods}

This was a prospective observational study that was conducted at King Abdulaziz University Hospital, Jeddah, Saudi Arabia, between January 1, 2003 and December 31, 2004. During the study period, all patients attending the obstetric antenatal clinic at King Abdulaziz University Hospital, a tertiary referral center, who had one or more risk factors were screened and subjected to a diagnostic test for GDM using the $100 \mathrm{~g}$ OGTT. Maternal risk factors for GDM included: family history of diabetes, previous large baby $\geq 4000 \mathrm{~g}$, previous stillbirth or infant with congenital anomaly, obesity and history of recurrent pregnancy loss. The $100 \mathrm{~g}$ OGTT was performed in the morning after an overnight fast of at least 8 hours (h) but not longer than $14 \mathrm{~h}$ and after at least 3 days of diet containing greater than $150 \mathrm{~g}$ of carbohydrates. After the ingestion of $100 \mathrm{~g}$ of glucose, the patients were instructed to remain seated and to not eat, drink, or smoke. The results were interpreted according to the recommendation of the American Diabetic Association (ADA), who proposed the adoption of the Carpenter and Coustan criteria for diagnosis of $\mathrm{GDM}^{[6-7]}$. Patients with GDM diagnosis, when $\geq 2$ abnormal values of the following venous plasma concentrations were met or exceeded: fasting $\geq 5.3 \mathrm{mmol} / \mathrm{L} ; 1 \mathrm{~h} \geq 10 \mathrm{mmol} / \mathrm{L} ; 2 \mathrm{~h} \geq 8.6 \mathrm{mmol} / \mathrm{L} ; 3 \mathrm{~h} \geq 7.8$ 
$\mathrm{mmol} / \mathrm{L}$. The inclusion criteria for the study were: 1) Singleton pregnancy, 2) patient having GDM diagnosis, 3) patient's regular attendance to the obstetric clinic, 4) minimal follow-up with fasting and $2 \mathrm{~h}$ postprandial plasma glucose levels. Exclusion criteria were: 1) multiple gestation and 2) diabetes mellitus [fasting plasma glucose level $(\mathrm{FPG}) \geq 7 \mathrm{mmol} / \mathrm{L}$, or 2 -h post-load glucose $11.1 \mathrm{mmol} / \mathrm{L}], 3$ ) Incomplete data records. The GDM patients were divided into two groups according to $100 \mathrm{~g}$ OGTT results; Group 1 normal fasting plasma glucose $<5.3 \mathrm{mmol} / \mathrm{L}$, and Group 2 impaired fasting plasma glucose $\geq 5.3 \mathrm{mmol} / \mathrm{L}$. The aim of glycemic control was to maintain all fasting plasma glucose values $<5.3 \mathrm{mmol} / \mathrm{L}(<95 \mathrm{mg} / \mathrm{dl})$ and all $2 \mathrm{~h}$ postprandial $<7.8 \mathrm{mmol} / \mathrm{L}(<140 \mathrm{mg} / \mathrm{dl})$. In case of GDM diagnosis, patient was informed and started on gestational diabetic diet after referral and counseling with dietitian. If the glycemic metabolic control (fasting and 2 $\mathrm{h}$ postprandial plasma glucose levels) was not achieved on diabetic dietary regimen alone, patients were admitted to the hospital for 24-h glucose profile (fasting and $2 \mathrm{~h}$ postprandial; breakfast, lunch, supper). An insulin injection was then added to control blood glucose levels. For diabetic purposes the pregnant patients were seen a minimum of once every two weeks, and with each follow-up visit a fasting and $2 \mathrm{~h}$ postprandial plasma glucose levels performed. Usually, the purpose of readmissions was either for obstetric reasons and/or control of blood glucose levels. The predictive variables that were likely to influence fetal outcome were noted. Maternal characteristics showed in Table 1.

Table 1. Maternal data on both groups.

\begin{tabular}{|l|c|c|c|}
\hline \multicolumn{1}{|c|}{ Variable } & $\begin{array}{c}\text { Group 1 } \\
(\mathbf{n = 1 8 2})\end{array}$ & $\begin{array}{c}\text { Group 2 } \\
(\mathbf{n = 1 1 0})\end{array}$ & p Values \\
\hline Age & $24.2 \pm 10.6$ & $25.5 \pm 11.1$ & NS \\
\hline Parity & $5.1 \pm 2.6$ & $5.2 \pm 2.7$ & NS \\
\hline BMI & $30.1 \pm 6.1$ & $31.3 \pm 5.3$ & NS \\
\hline
\end{tabular}

$B M I=$ Body mass index, Data are given as means $\pm S D$

The gestational age (based on last menstrual period and or ultrasound measurements) at the diagnosis and delivery of GDM patients, mode of treatment and the arithmetic means of all fasting and $2 \mathrm{~h}$ postprandial plasma glucose values prior to delivery presented in (Table 2). After delivery, the following outcome measures were recorded: fetal birth weight, 
macrosomic baby $\geq 4000 \mathrm{~g}$, cesarean delivery, and perinatal mortality and morbidity (Table 3). Statistical analysis was performed using Statistical Package for the Social Sciences (SPSS), Version 11, for Windows as appropriate. The percentage $(\%)$ or means $\pm \mathrm{SD}$, "Student's" $t$-test for continuous variables, and Chi-square test or Fisher exact test for categorical data were used. Odd ratio (OR) and the $95 \%$ confidence intervals (CI) were computed. Further, to address the effects of confounding variables of macrosomia (maternal age, parity, body mass index, and gestational delivery weeks), multiple logistic regression analyses were performed. A $p$ value $<.05$ was considered as statistically significant.

Table 2. Gestational age diagnosis, delivery weeks, treatment and degree of glycemia control on both groups.

\begin{tabular}{|l|c|c|c|}
\hline \multicolumn{1}{|c|}{ Variable } & $\begin{array}{c}\text { Group 1 } \\
(\mathbf{n = 1 8 2})\end{array}$ & $\begin{array}{c}\text { Group 2 } \\
(\mathbf{n = 1 1 0})\end{array}$ & p Values \\
\hline GTT performed (Weeks) & $27 \pm 8.2$ & $23.5 \pm 9.1$ & NS \\
\hline Delivery weeks & $38.4 \pm 2.0$ & $38.5 \pm 1.3$ & NS \\
\hline Treatment: & $145(79.7 \%)$ & $66(60 \%)$ & 0.0001 \\
\hline Diet & $37(20.3 \%)$ & $44(44 \%)$ & 0.0001 \\
\hline Insulin & $4.7 \pm 0.5$ & $6.6 \pm 2.0$ & 0.0001 \\
\hline Mean FPG & $6.6 \pm 1.4$ & $8.1 \pm 2.3$ & 0.0001 \\
\hline Mean-2h PP PG &
\end{tabular}

Data are given as means $\pm S D$ and \% as appropriate. FPG; fasting plasma glucose, 2-h PP PG; 2-h postprandial plasma glucose

\section{Results}

During the study, period a total of 292 patients met the inclusion criteria. One hundred eighty-two $(62.3 \%)$ with $\mathrm{N}-\mathrm{FPG}<5.3 \mathrm{mmol} / \mathrm{L}$ and $110(37.7 \%)$ patients having I-FPG $\geq 5.3 \mathrm{mmol} / \mathrm{L}$. The maternal characteristics (age, parity, body mass index) of both groups were comparable and not statistically significant (Table 1).

The gestational age at the diagnosis of GDM and time of delivery weeks on both groups were also statistically not different. Majority of patients Group 1 need only diet control (80\%) vs. (60\%) in - Group 2 (OR 1.3, 95\%; CI 1.1-1.6; p. 0.0001). Whereas Group 2 (44\% vs. 20\%) required more insulin treatment, (OR 2.6 95\% CI 1.6-4.4; $p$ 0.0001), and 
with less in-Group 1, respectively (Table 2). Regarding the metabolic control of glycemia for GDM patients, the mean \pm SD concentrations of fasting and postprandial plasma glucose measurements were significantly lower in-Group 1 compared with Group 2 ( $p$ 0.0001).

The outcome of pregnancy for both groups is presented in Table 3. The percentage (\%) of total and primary cesarean delivery is higher in Group 2 and it is statistically different. The mean \pm SD fetal birth weight was heavier in Group 2 and also the macrosomic babies were not statistically significant when compared to Group 1. Within each group, a logistic regression analysis model was run with the predictive variables as independent variables and each of the outcome measures as dependent variables. The results showed that Group 2 patients with impaired fasting plasma level $\geq 5.3 \mathrm{mmol} / \mathrm{L}$ have a significant positive effect on birth weight $(p=0.04)$. None of the other predictive variables appeared to be independently have a significant effect on any of the studied outcome measures.

Table 3. Outcome measures of both groups.

\begin{tabular}{|l|c|c|c|}
\hline \multicolumn{1}{|c|}{ Variable } & $\begin{array}{c}\text { Group 1 } \\
(\mathbf{n = 1 8 2})\end{array}$ & $\begin{array}{c}\text { Group 2 } \\
(\mathbf{n = 1 1 0})\end{array}$ & $\boldsymbol{p}$ Values \\
\hline Mode of Delivery & & & 0.002 \\
\hline Vaginal Delivery & $157(86.3 \%)$ & $79(71.8 \%)$ & \\
\hline Total Cesarean Section & $25(15.3 \%)$ & $31(28.2 \%)$ & \\
\hline Primary CS & $14(7.7 \%)$ & $16(14.5 \%)$ & \\
\hline Fetal Distress & $3(1.7 \%)$ & $10(9.1 \%)$ & \\
\hline Failure to Progress & $11(6.0 \%)$ & $6(5.4 \%)$ & \\
\hline Fetal Weight $(\mathrm{g})$ & $3373.4 \pm 580.3$ & $3477.1 \pm 542.9$ & $\mathrm{NS}$ \\
\hline Macrosomia & $21(11.5 \%)$ & $17(15.5 \%)$ & $\mathrm{NS}$ \\
\hline AS $<5$ at 1 minute & $7(3.8 \%)$ & $3(2.7 \%)$ & $\mathrm{NS}$ \\
\hline AS $<5$ at 5 minute & $2(1.1 \%)$ & $1(0.9 \%)$ & $\mathrm{NS}$ \\
\hline Hypoglycemia & $2(1.1 \%)$ & $3(2.7 \%)$ & $\mathrm{NS}$ \\
\hline SCBU & & $1(\% 0.9)$ & \\
\hline
\end{tabular}

Data are given as means \pm (S.D) and \% as appropriate. Cesarean section, Macrosomia; baby weight $\geq 4000$ g, AS; Apgar score, SCBU; special care baby unit.

The Apgar score $<5$ at 1 and 5 minutes and hypoglycemia were statistically not different in both groups. There was one newborn admission to special care baby unit (SCBU) in Group 2 and there was no prenatal mortality in either groups. 


\section{Discussion}

There is insufficient evidence to recommend routine screening for $\mathrm{GDM}^{[8,9]}$. The randomized control trials documenting improvement of perinatal mortality and morbidity as a result of routine screening are lacking ${ }^{[10,11]}$. Santini et al. have reported that routine screening failed to decrease the rate of macrosomia $(10.5 \%$ in the unscreened group $v s$. $11.2 \%$ in the screened group) and also, was associated with more intensive surveillance during pregnancy and a higher rate of cesarean delivery $(21 \% \text { vs. } 26.7 \% ; \mathrm{p}<0.01)^{[12]}$. Similarly, selective screening is not without problems. Coustan et al. showed in a population-based study that one-third to one-half of patients with gestational diabetes would be missed by the selective screening approach ${ }^{[7]}$. One may conclude that the best description of the current state of the knowledge regarding screening pregnant patients for GDM is uncertainty. There is still no consensus on practices of obstetricians to screen or diagnose GDM.

The diagnosis of GDM is so controversial that the American Diabetes Association and the American College of Obstetricians and Gynecologists support different criteria for its diagnosis. Carpenter and Coustan criteria were used. Magee et al. reported 50\% more cases of gestational diabetes were identified, with the use of the Carpenter and Coustan thresholds, which is the more inclusive for the GDM $\operatorname{diagnosis}^{[13]}$.

The advantages of using FPG are: it is not affected by gestational age, it is similar in different ethnic patients, and that it has less variability and better reproducibility ${ }^{[14]}$. When the FPG level of the OGTT was taken into consideration $(<5.3$ vs. $\geq 5.3 \mathrm{mmol} / \mathrm{L})$, two different populations could be distinguished with the same diagnosis. They were not only different in their glycemic response during the OGTT, but their metabolic glycemic control of the means $\pm \mathrm{SD}$ of fasting and $2 \mathrm{~h}$ postprandial level measurements during follow-up prior to delivery was significantly lower in Group 1. Furthermore, the majority of GDM patients in Group 1 were managed by diet regimen and required less insulin (OR 2.6 95\% CI 1.6-4.4; $p$ 0.0001). This means some difference on the perinatal outcome measures expected, mainly incidence of macrosomia and cesarean delivery. Although, in Group 2 the fetal birth weight was greater than that of Group 1, the percentage of macrosomic babies $15.5 \%$ vs. $11.5 \%$ (OR $0.895 \%$ CI $0.4-1.4 ; p 0.2$ ) was also not 
statistically different. It may be that blood glucose level is a marker of a metabolic state associated with higher risk, rather than the direct cause of complications. Similar results have been observed by some authors who have found that after adjusting for maternal age, parity, and maternal body weight there was no correlation between blood glucose level and neonatal birth weight ${ }^{[3,15,16]}$. A Naylor et al. study reported that cesarean sections were more common in patients diagnosed as having GDM and it was seen in those with no macrosomia ${ }^{[17]}$. Nevertheless, the primary cesarean delivery in Group $2(14.5 \% v s .7 .7 \%)$ was almost double that of Group 1 ( $p$ 0.002).

GDM is defined as "carbohydrate intolerance of variable severity with onset during pregnancy with return to normal after delivery",[6]. There is no threshold that clearly distinguishes between low-risk and high-risk GDM patients. Nasrat et al. reported that the defining of the GDM according to the severity of glucose intolerance should be emphasized $^{[18]}$. The study results showed that Group 2 patients with impaired fasting plasma level $\geq 5.3 \mathrm{mmol} / \mathrm{L}$ have significant positive effect on birth weight $(p=0.04)$. Recently, Nordin et al. found impaired fasting glucose level which appeared as an important predictor for increased risk of maternal/fetal morbidity ${ }^{[19]}$. Also, Lin et al. found that the fasting glucose value for $100 \mathrm{~g}$ OGTT is an independent risk factor and more than three abnormal glucose values offer good diagnostic efficacy in predicting postpartum glucose intolerance ${ }^{[20]}$.

Patients with N-FPG $<5.3 \mathrm{mmol} / \mathrm{L}$ during $100 \mathrm{~g}$ OGTT are better classified as lesser degrees of glucose intolerance or mild gestational hyperglycemia $(\mathrm{MGH})^{[18-19]}$. Furthermore, in long-term post delivery follow-up the risk of the development of abnormal GTT is significantly small ${ }^{[21]}$. A study involving a large number of patients is needed for documenting the performance of impaired fasting plasma glucose patients to predict perinatal outcomes. Furthermore, it is protocol to perform OGTT in these patients at 6 weeks postnatal, but unfortunately, due to the incompliance of patients and a lack of follow-up, these results were unavailable.

For those patients with multiple risk factors, a screening and diagnosis for GDM should be offered. Those patients with abnormal OGTT, including impaired fasting plasma glucose should be considered as having a severe form of GDM which implies a pathological state of 
glucose intolerance, i.e. an impaired ability of $\beta$-cells to further increase insulin secretion in response to glucose; such diagnosis needs intensive clinical monitoring and more aggressive insulin therapy to achieve normal birth weight. Whereas, patients with normal fasting plasma glucose $<5.3 \mathrm{mmol} / \mathrm{L}$ may need ordinary follow-up rather than frequent surveillance.

\section{References}

[1] Persson B, Stangenberg M, Hansson U, Nordlander E. Gestational diabetes mellitus (GDM). Comparative evaluation of two treatment regimens, diet versus insulin and diet. Diabetes 1985; 34(Suppl 2): 101-105.

[2] de Veciana M, Major CA, Morgan MA, Asrat T, Toohey JS, Lien JM, Evans AT. Postprandial versus preprandial blood glucose monitoring in women with gestational diabetes mellitus requiring insulin therapy. N Engl J Med 1995; 333(19): 1237-1241.

[3] Nordlander E, Hanson U, Persson B. Factors influencing neonatal morbidity in gestational diabetic pregnancy. Br J Obstet Gynaecol 1989; 96(6): 671-678.

[4] Kwik M, Seeho SK, Smith C, McElduff A, Morris JM. Outcome of pregnancies affected by impaired glucose tolerance. Diabetes Res Clin Pract 2007; 77(2): 263-268.

[5] Pallardo F, Herranz L, Garcia-Ingelmo T, Grande C, Martin-Vaquero P, Jañez M, Gonzalez A. Early postpartum metabolic assessment in women with prior gestational diabetes. Diabetes Care 1999; 22(7): 1053-1058.

[6] American Diabetes Association. Gestational diabetes mellitus. Diabetes Care 1998; 21 (Supply 1): B1 B167.

[7] Coustan DR, Nelson C, Carpenter MW, Carr SR, Rotondo L, Widness JA. Maternal age and screening for gestational diabetes: a population-base study. Obstet Gynecol 1989; 73(4): 557-561.

[8] Brody SC, Harris R, Lohr K. Screening for gestational diabetes: a summary of the evidence for the US Preventive Services Task force. Obstet Gynecol 2003; 101(2): 380-392.

[9] Greene MF, Solomon CG. Gestational diabetes mellitus -- time to treat. $N$ Engl J Med 2005; 352(24): 2544-2546.

[10] [No authors listed]. Periodic health examination, 1992 update: 1. Screening for gestational diabetes mellitus. Canadian Task Force on the Periodic Health Examination. CMAJ 1992; 147(4): 435-443.

[11] US Preventive Services Task Force. Guide to Clinical Preventive Services: Report of the US Preventive Services Task Force, $2^{\text {nd }}$ ed. Baltimore: Williams and Wilkins, 1996. 193208.

[12] Santini DL, Ales KL. The impact of universal screening for gestational glucose intolerance on outcome of pregnancy. Surg Gynecol Obstet 1990; 170(5): 427-436.

[13] Magee MS, Walden CE, Benedetti TJ, Knopp RH. Influence of diagnostic criteria on the incidence of gestational diabetes and perinatal morbidity. JAMA 1993; 269(5): 609-615.

[14] Perucchini D, Fischer U, Spinas GA, Huch R, Huch A, Lehmann R. Using fasting plasma glucose concentration to screen for gestational diabetes mellitus: prospective population based study. BMJ 1999; 319(7213): 812-815.

[15] Spellacy WN, Miller S, Wineger A, Peterson PQ. Macrosomia-maternal characteristics and infant complications. Obstet Gynecol 1985; 66(2): 158-161. 
[16] Green JR, Schumacher LB, Pawson IG, Partridge JC, Kretchmer N. Influence of maternal body habitus and glucose tolerance on birth weight. Obstet Gynecol 1991; 78(2): 235-240.

[17] Naylor CD, Semer M, Chen E, Sykora K. Cesarean delivery in relation to birth weight and gestational glucose tolerance: pathophysiology or practice style? Toronto Trihospital Gestational Diabetes Investigators. JAMA 1996; 275(15): 1165-1170.

[18] Nasrat H, Fageeh W, Abalkhail B, Yamani T, Ardawi MS. Determinants of pregnancy outcome in patients with gestational diabetes. Int J Gynecol Obstet 1996; 53(2): 117-123.

[19] Nordin NM, Wei JW, Naing NN, Symonds EM. Comparison of maternal-fetal outcomes in gestational diabetes and lesser degrees of glucose intolerance. J Obstet Gynecol Res 2006; 32(1): 107-114.

[20] Lin CH, Wen SF, Wu YH, Huang YY, Huang MJ. The postpartum metabolic outcome of women with previous gestational diabetes. Chang Gung Med J 2005; 28(11): 794-800.

[21] Weijers RN, Bekedam DJ, Smulders YM. Determinants of mild gestational hyperglycemia and gestational diabetes mellitus in a large Dutch multiethnic cohort. Diabetes Care 2002; 25(1): 72-77. 
مرضى سكري الحمل في عينة سكانية عالية الخطورة:

نتائج فنزة ما حول الو لادة عند وجود معدل غير طبيعي

$$
\text { لعينة صيام البلازما جلوكوز }
$$

\section{طارق يوسف يماني الزمزمي}

قسم أمراض النساء والتوليد، كلبة الطب، جامعة الملك عبد/لعزيز

$$
\text { جـدة - المملكة العربية السعودية }
$$

العستخلص. العهف من هذه الدارسة هو مقارنة نتائج فترة ما حول

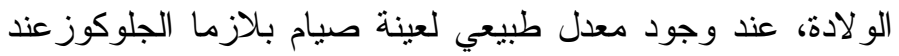

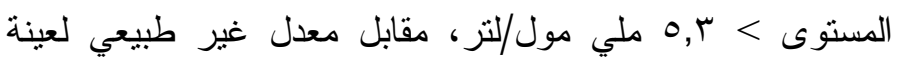

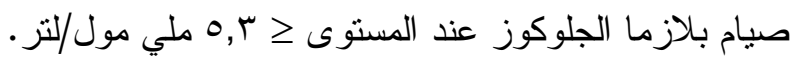

تم تنخيص جميع مرضى سكر الحمل اللاتي فحصن خلال

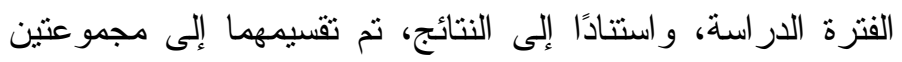

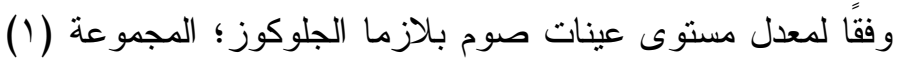

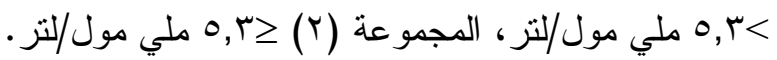

خلال فترة الدراسة كان هنالك بوب مريضة تم تثخيصهن

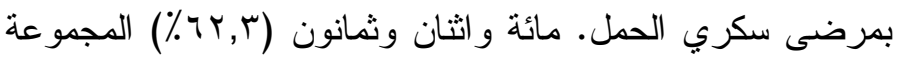

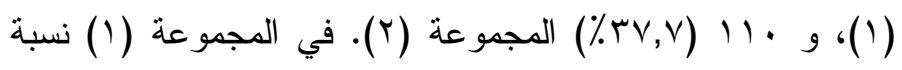

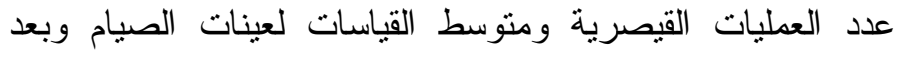

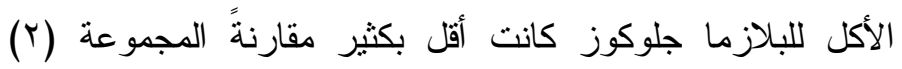

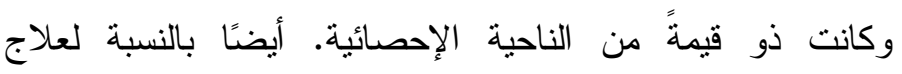

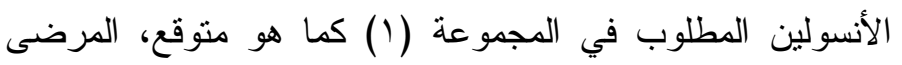


أقل عددًا مقارنةً مع المجموعة (Y)، وكانت ذات قيمة من الناحية الإحصائية.

عند وجود معدل غير طبيعي لعينة صيام بلازما الجلوكوز للمرضى، فإنهن في حاجة إلى المزيد من علاج الأنسولين و المرتبطة بارتفاع معدل الولادة القيصرية مقارنةً للمرضىى عند وجود معدل طبيعي لعينة صيام بلازما الجلوكوز، ويحتجن إلى متابعة عادية غير متو اترة المر اقبة. 
